Creative Commons User License: CC BY-NC-ND

Abstracted by: EBSCOhost, Electronic Journals Service (EJS),

Google Scholar, Journal Seek, Scientific Commons,

Food and Agricultural Organization (FAO), CABI and Scopus
Journal of Agricultural Extension

Vol. 23 (4) October, 2019

ISSN(e): 24086851; ISSN(Print); 1119944X

http://journal.aesonnigeria.org

http://www.ajol.info/index.php/iae

Email: editorinchief@aesonnigeria.org

Actors' Satisfaction with Poultry Value Chain Approach of the Commercial Agricultural Development Project in Enugu State, Nigeria

https://dx.doi.org/10.4314/jae.v23i4.17

\title{
Udoye, Charles Ekene
}

Department of Agricultural Extension, University of Nigeria, Nsukka

Email:charles.udoye@gmail.com

charles.udoye@unn.edu.ng

Phone number: 07066077159

\section{Dimelu, Mabel Ukamaka}

Department of Agricultural Extension,

University of Nigeria, Nsukka

Email: mabel.dimelu@unn.edu.ng

Phone number: 08143913561

\section{Anugwa, Ifeoma $\mathbf{Q}$.}

Department of Agricultural Extension, University of Nigeria, Nsukka

Email: ifeoma.irohibe@unn.edu.ng

Phone number: 08065435735

\section{Ozioko, Remigius I.}

Department of Agricultural Extension, University of Nigeria, Nsukka

Email: ikechiozioko@gmail.com

Phone number: 07038845649

\section{Azubuike, Favour C.}

Department of Agricultural Extension,

University of Nigeria, Nsukka

Email: favourazubuike@gmail.com

Phone number: 08103422658

\section{Abstract}

The study ascertained actors' perception of the poultry value chain approach of the Commercial Agricultural Development Project (CADP) in Enugu State, Nigeria. Seventy-one poultry value chain (PVC) actors constituted the sample for the study. Data were analysed using percentages, charts and mean scores. Results show that all (100\%) the service providers provided information on how to use drugs and vaccines. The proportion of producers that reared broiler in 2010 were 51\% which attained a peak level of 55.8\% in 2011 and slightly declined thereafter, while 49\% of them reared layers in 2010, which declined to 44.2\% in 2011 and continued with an undulating trend. Generally, the actors perceived the poultry value chain approach of CADP satisfactory. The service providers and producers were satisfied with linkage with other actors in the poultry value chain $(\bar{x}=2.50)$ while the processors were satisfied with frequency of contact with facilitators $(\bar{x}=3.00)$. Major constraints to the effective performance of the PVC actors identified by 
Creative Commons User License: CC BY-NC-ND

Abstracted by: EBSCOhost, Electronic Journals Service (EJS), Google Scholar, Journal Seek, Scientific Commons,

Food and Agricultural Organization (FAO), CABI and Scopus
Journal of Agricultural Extension

Vol. 23 (4) October, 2019

ISSN(e): 24086851; ISSN(Print); 1119944X

http://journal.aesonnigeria.org

http://www.ajol.info/index.php/jae

Email: editorinchief@aesonnigeria.org

the producers include; high cost of accessing information from web ( $\bar{x}=4.00)$. Also, processors' and marketers perceived constraints were lack of trust in communicating with other actors $(\bar{x}=2.50)$ and low literacy level of actors $(\bar{x}=3.00)$, respectively. Government and donor agencies should ensure timely supply of inputs for actors at the different value chain segments to ensure efficient and productive chain activity.

Keywords: CADP, extension service, poultry, value chain actors.

\section{Introduction}

Agriculture has been an important sector in the Nigerian economy in the past decades, and is still a major sector, despite the oil boom (Noko, 2016). It employs about two-thirds of Nigeria's labour force and provides a large proportion of non-oil earnings (Antai, Udo and Effiong, 2016). However, advances in literature, show that its contribution to the economic growth of the nation has been declining over the years. Ekpo and Umoh (2012) revealed that the contribution of agriculture to the GDP was $63 \%$ in 1960 , and declined to $50 \%$ in 1970 ; as well as $34 \%$ each in 1988 and 2003. More recent empirical data show that its contribution declined from $37.05 \%$ in $2000-2004$, to $33.50 \%$ in $2005-2009$ and accelerated to $37.02 \%$ in 2010 2012 (CBN Statistical Bulletin, 2010; Ahungwa, Haruna, and Rakiya, 2014). However, its contribution to the overall GDP declined to 29.15\% in 2017 (National Bureau of Statistics, NBS, 2017). This was due to years of mismanagement, inconsistency in the government policies and the era of huge oil revenues. Consequently, the nation's goals to attain food security, increase income and eradicate poverty of the people, particularly rural population have remained a mirage, despite the existing potential in human and natural resources (Achimugu, Abubakar, Agboni, Orokpo, 2012).

According to Obiora and Emodi (2013) the Nigerian agricultural sector has evolved over the years through performing traditional "supply push" approach with emphasis on production. Many approaches demonstrated tendency to strengthen the supply capacity of producers and small companies without having a confirmed order and with erroneous assumption that a market would be available, which sometimes was the case and often not. Other weaknesses identified include high post-harvest losses, neglect of institutional and policy factors that impact on agricultural innovation (Klerkx, Schut, Leeuwis and Kilelu, 2012); and weak interaction and communication linkage between economic actors in agricultural innovation system.

In a bid to ameliorate the situation and bring about a change in status quo, the Nigerian government has variously initiated and implemented many agricultural development programmes/projects including the Commercial Agricultural Development Project (CADP) which was one of the World Bank investment projects. The project was implemented in five states namely: Cross River, Enugu, Lagos, Kaduna, and Kano States along eight value chains (VCs) (Enugu State Commercial Agricultural Development Project (ENSCADP), 2013). The beneficiaries of the project were aggregated into commodity interest groups (CIGs) which are legally registered (Anyadiegwu, 2013). The project supported three value chains (VC) per state. The VCs were distributed thus: Cross River (Oil Palm, Cocoa, and Rice), 
Creative Commons User License: CC BY-NC-ND

Abstracted by: EBSCOhost, Electronic Journals Service (EJS), Google Scholar, Journal Seek, Scientific Commons,

Food and Agricultural Organization (FAO), CABI and Scopus
Journal of Agricultural Extension

Vol. 23 (4) October, 2019

ISSN(e): 24086851; ISSN(Print); 1119944X

http://journal.aesonnigeria.org

http://www.ajol.info/index.php/jae

Email: editorinchief@aesonnigeria.org

Enugu (Fruit Trees, Poultry, and Maize), Kaduna (Fruits Trees, Dairy, and Maize), Kano (Rice, Dairy, and Maize) and Lagos (Poultry, Aquaculture, and Rice) (National Bureau of Statistics (NBS)/CADP Baseline Survey Report, 2010). The VCs chosen by each of the participating states were based on the respective comparative advantage and their contribution to agricultural growth. Enugu State has comparative advantage for commercialization of poultry production. Among the livestock reared, poultry predominates with a population of about 372,400 poultry compared to cattle $(27,782)$, sheep $(16,928)$, goats $(64,777)$, pigs $(7,534)$, horses $(80)$, donkeys $(2$, 5210) (Ugwu, 2009). Similarly, the National Bureau of Statistics (NBS)/CADP Baseline Survey Report (2010) shows that chicken is the most preferred poultry product in Enugu State with $97.8 \%$, followed by ostrich $0.9 \%$, turkey $0.4 \%$ while guinea fowl and duck recorded $0 \%$ each. Its potential hinges on the existence of huge market, human, economic, social and cultural opportunities for its product in the state. Thus, the adoption of value chain development approach of CADP becomes paramount in stimulating economic growth and increasing the competitiveness of the poultry sub- sector.

Value chains are chains that incorporate all the activities and services that are undertaken along a commodity system from the primary producers to the final consumer (Haggblade, Theriault, Staatz, Dembele and Diallo, 2012). Poultry VCs on the other hand describes the processes through which birds and other inputs pass during the production process, including information on the place each process occurs and on the people involved. The processes range from input supply, production, processing, marketing and consumption with heterogeneous actors at each stage of the chain. This indicates that farmers, however, need training to play gainful roles in the agro-food industry. Training on chain development techniques is a sure way of empowering small-scale farmers to engage with suppliers and buyers of their produce. Farmers increasingly need the knowledge and skills to compete in the new farming environment. They may need to develop or adopt new technologies, diversify their production and identify and exploit new market opportunities.

\section{Objective of the study}

The overall purpose of the study was to ascertain actors' satisfaction of the poultry value chain approach of the Commercial Agricultural Development Project in Enugu State, Nigeria. Specifically, the study sought to:

1. describe the actors in the poultry value chain;

2. ascertain actors' satisfaction of the value chain approach; and

3. challenges of actors in poultry value chain of CADP.

\section{Methodology}

The study was carried out in Enugu State, Nigeria. Enugu State is located in the South-East geo-political zone of Nigeria between latitudes $58^{\circ} 50^{\prime}$ and $78^{\circ} 01^{\prime}$ North and longitudes $68^{\circ} 50^{\prime}$ and $78^{\circ} 55^{\prime}$ East. The State has seventeen local government areas and six agricultural zones. Actors in poultry value chain in Enugu State CADP constituted the population for the study. Two out of the five poultry service providers that benefitted from ENSCADP were selected. From the list of $85 \mathrm{CIGs}$ in poultry production, 64 producers were selected. From the list of five CIGs in poultry 
Creative Commons User License: CC BY-NC-ND

Abstracted by: EBSCOhost, Electronic Journals Service (EJS), Google Scholar, Journal Seek, Scientific Commons,

Food and Agricultural Organization (FAO), CABI and Scopus
Journal of Agricultural Extension

Vol. 23 (4) October, 2019

ISSN(e): 24086851; ISSN(Print); 1119944X

http://journal.aesonnigeria.org

http://www.ajol.info/index.php/jae

Email: editorinchief@aesonnigeria.org

processing made available by the monitoring and evaluation officer of ENSCADP, two poultry processors were randomly selected. Three poultry marketers were selected from the list of available eight CIGs. This gave a total of two service providers, sixty-four poultry farmers, two processors and three marketers. A grand total of seventy-one (71) core value chain actors participated in the study. Data were collected using structured interview schedule. Age of the respondents and years of experience in poultry production, processing or marketing were collected in years.

The respondents were requested to state the structure of their poultry farm including: number of birds kept, type of production (e.g. broilers and layers). They were further requested to indicate their channel of product delivery (e.g. assemblers, individual consumers, wholesalers, retailers etc.) and the proportion of sales to these sources. The actual proportion sold to the channels was gotten by multiplying the frequency by the proportion (using 10 fingers as 100\%) indicated, divided by number of respondents.

Wealth class was gotten by asking the respondents to tick yes or no, from a list of wealth indicators (assets owned) and also state the number of assets owned. Such assets include land ownership, type of house owned and other assets. Individual items were scored as follows: bicycle $=1$, motorbike $=2$; watch or clock $=1$, modern stove $=2$, radio $=3$, generator $=4$, refrigerator $=5$, television $=6$, mobile phone $=7$, gas cooker $=8$, personal computer $=9$, hectare of land $=10$; thatched house with walls made of grass without latrines $=1$, mud house with thatched roof with kitchen and latrines $=2$, mud house with zinc roof $=3$, brick house with zinc roof $=4$, concrete house with zinc $=5$ and painted zinc/concrete house $=6$. Each item score was multiplied by the number owned which gave a wealth value for the particular respondent. Each respondent's wealth status was gotten by adding up all the value from respective items owned. They were further ranked as very poor (0-50), poor (51-100), middle class (101-150), rich (151-200) and very rich (201 and above).

The satisfaction of value chain was measured on a 5-point Likert-type scale of most satisfactory $=4$, very satisfactory $=3$, satisfactory $=2$, less satisfactory $=1$ and not satisfactory $=0$. The values were added and divided by 5 to give a mean score of 2.0. Any variable with mean value equal or greater than 2.0 was regarded as satisfactory, while variables with mean scores less than 2.0 was not satisfactory. Some of the variables include: time of input supply, quality of extension service provided, grants and other funds received. Similarly, the challenges faced by actors in the poultry value chain were ascertained using a 5-point Likert-type scale ( major $=4$, moderate $=3$, neutral $=2$, minor $=1$, and none $=0$ ) with a mean of 2.0. In order to obtain a cut-off point, 0.05 was added to the mean to get 2.05 and used as the upper limit while 0.05 was deducted from the mean to get 1.95 which was used as lower limit. Any response option with mean greater than or equal to 2.05 were regarded as a constraint. Data on socio-economic characteristics were analysed with percentage and mean score, data on description of actors in poultry value chain was analysed using percentage and graph. Data on perception of actors on value chain and challenges faced by actors were analysed using mean score. These analyses were executed with IBM-SPSS Statistical Package, version 22. 
Creative Commons User License: CC BY-NC-ND

Abstracted by: EBSCOhost, Electronic Journals Service (EJS), Google Scholar, Journal Seek, Scientific Commons,

Food and Agricultural Organization (FAO), CABI and Scopus
Journal of Agricultural Extension

Vol. 23 (4) October, 2019

ISSN(e): 24086851; ISSN(Print); 1119944X

http://journal.aesonnigeria.org

http://www.ajol.info/index.php/iae

Email: editorinchief@aesonnigeria.org

\section{Results and Discussions}

\section{Activities of Actors in Poultry Value Chain}

Service providers: Table 1 shows that all (100\%) service providers provided information on how to use drugs and vaccines, training and advisory services, disease control, information on hazards associated with abuse of drugs and vaccines respectively, while $50 \%$ supply day old chicks, poultry feed, hatchery equipment, battery cage, drinking and feeding trough, feedstuffs/ingredients, among others. This shows that the service providers are engaged in delivering several services to actors in the poultry value chain.

\section{Table 1: Type of services and products provided}

\begin{tabular}{|c|c|}
\hline $\begin{array}{l}\text { "Type of services and products provided (service } \\
\text { providers) }\end{array}$ & $\%(\mathbf{n}=\mathbf{2})$ \\
\hline Day old chick & 50 \\
\hline Poultry feed & 50 \\
\hline Hatchery equipment & 50 \\
\hline Battery cage & 50 \\
\hline How to use drugs and vaccines & 100 \\
\hline Drinking and feeding trough & 50 \\
\hline Training and advisory services & 100 \\
\hline Feedstuffs/ingredients & 50 \\
\hline Disease control & 100 \\
\hline $\begin{array}{l}\text { Information on hazards associated with abuse of drugs } \\
\text { and vaccines }\end{array}$ & 100 \\
\hline How to identify standard/adulterated drugs/vaccines & 50 \\
\hline
\end{tabular}

\section{*Multiple responses}

Field survey, 2017

Producers (Type of bird produced): Figure 1 shows that the proportion of producers that reared broiler in 2010 was 51\% which peaked (55.8\%) in 2011 and slightly declined to $51.9 \%$ in 2012 and continued with a varying trend in 2013, 2014, 2015 and 2016. A similar trend was observed among the producers that reared layers with $49 \%$ of them rearing layers in 2010, which declined to $44.2 \%$ in 2011 and continued with varying trends in 2012 and 2013 before it peaked at $50 \%$ in 2014 and then declined $45 \%$ in 2016 . It can be inferred that the beneficiaries (producers) are engaged in both broiler and layers production. However, greater numbers of the producers are involved in broiler production except in 2014. This suggests a quicker return on investment in broiler production. The undulating trend in the type of production probably shows that producers are trying to find a balance with the demand of poultry meat and egg while being cautious of surplus. 


\section{Type of bird produced}

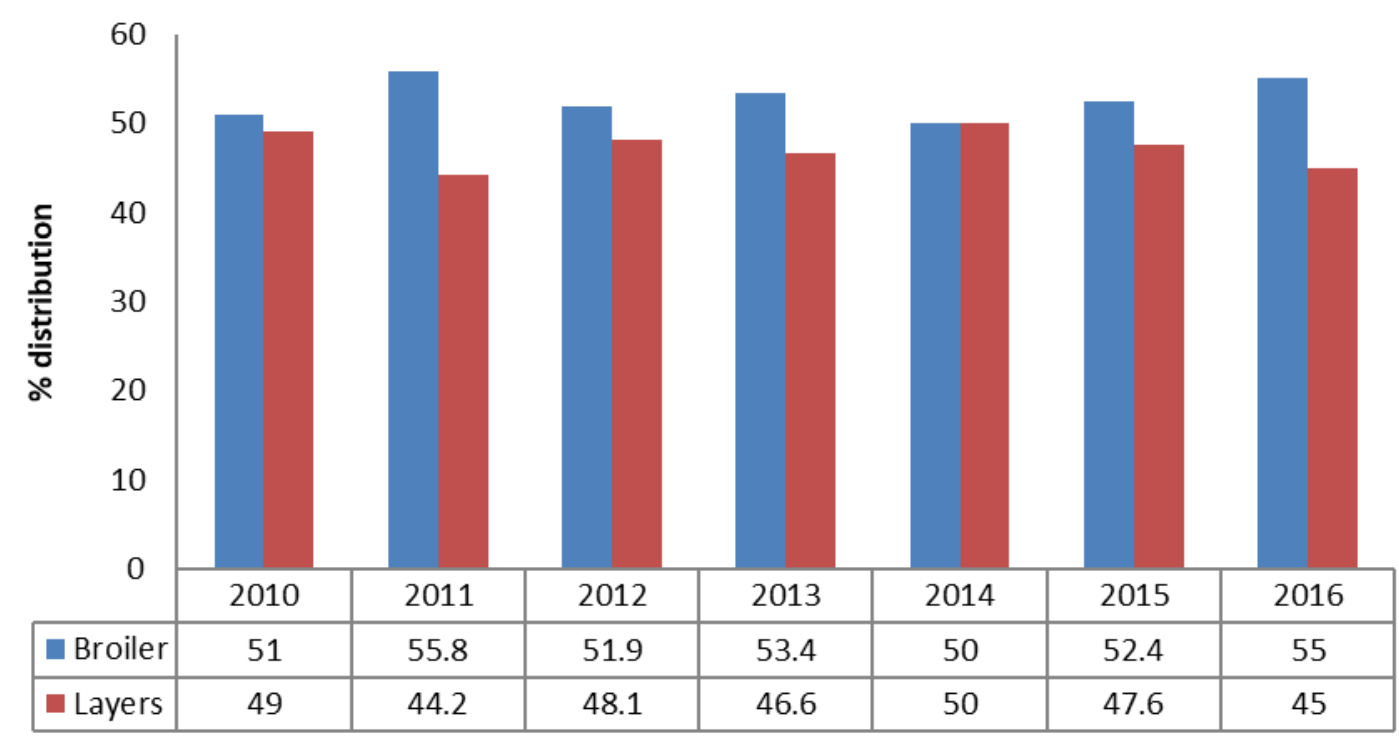

Figure 1: Type of poultry produced

Source: Field survey, 2017

Producers (Number of birds stocked): Figure 2 shows that the mean number of birds stocked in 2010 was 2,225 birds which steadily increased across the period under consideration; with 2,569 birds in 2011 to 4,678 birds in 2016. This means about $95 \%$ increase in production across the years. This is attributed to several factors including demand, technical know-how and profitability among others. According to FAO (2013), chicken meat production in Africa between 2006 and 2013 increased steadily by almost $5 \%$ per year. Increased preference for poultry products could be attributed to the ecological, economic, social and health advantages they have over other types of food stuffs (Heise, Crisan and Theuvsen, 2015). 
Creative Commons User License: CC BY-NC-ND

Abstracted by: EBSCOhost, Electronic Journals Service (EJS), Google Scholar, Journal Seek, Scientific Commons,

Food and Agricultural Organization (FAO), CABI and Scopus

http://eoi.citefactor.org/10.11226/v23i4
Journal of Agricultural Extension

Vol. 23 (4) October, 2019

ISSN(e): 24086851; ISSN(Print); 1119944X

http://journal.aesonnigeria.org

http://www.ajol.info/index.php/jae

Email: editorinchief@aesonnigeria.org

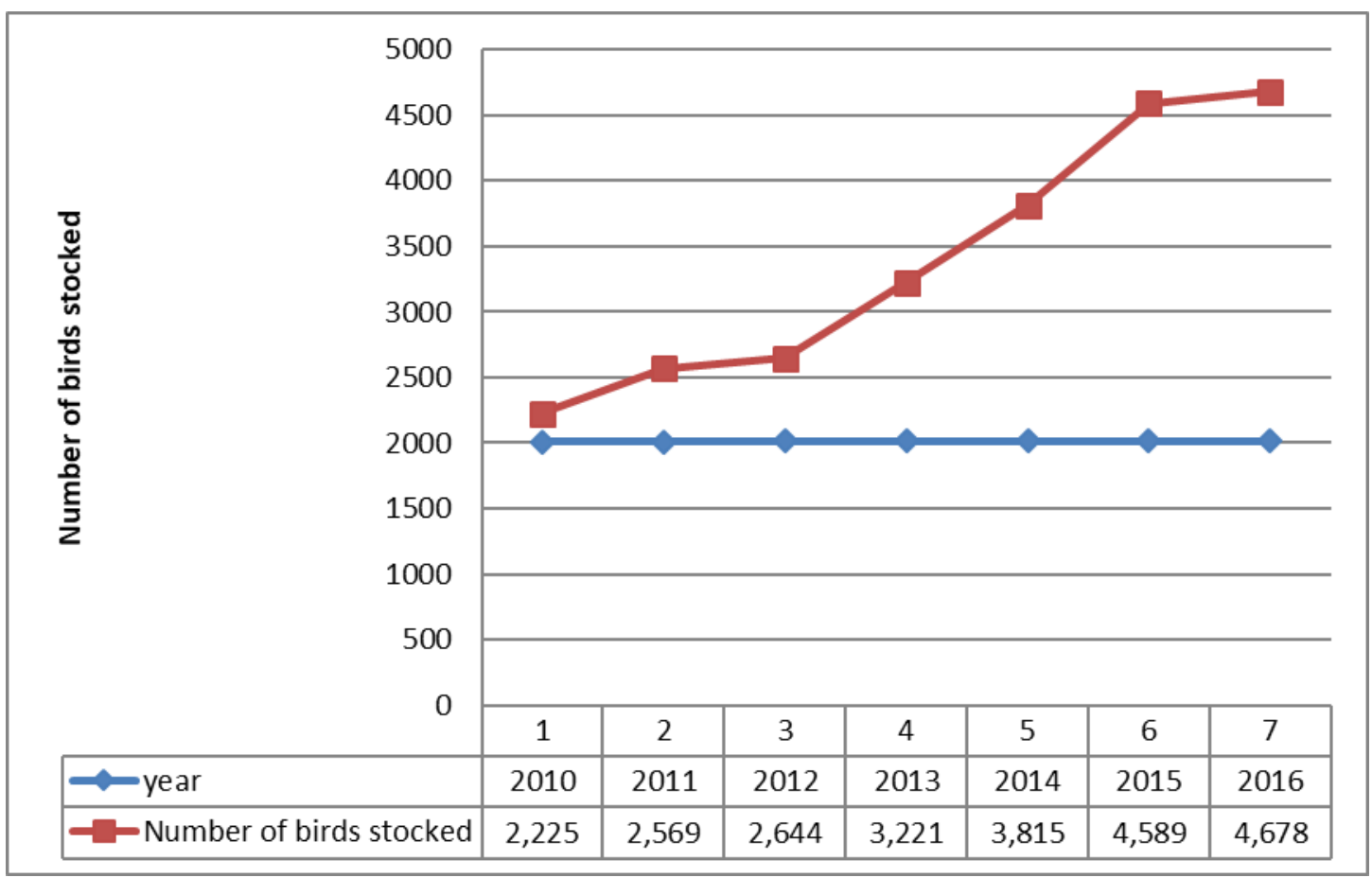

Figure 2: Number of birds stocked

Source: Field survey, 2017

Processors (Commodity processed): Trend in number of broilers processed as shown in Figure 3 indicates that broilers processed was 150,000 birds in 2011 which increased to 180,000 birds in 2012 and peaked (275,000 birds) in 2013 but declined to 115,000 birds in 2016 . The number of culled layers processed was 50,000 birds in 2013 and peaked (90,000 birds) in 2014, before undulating in 2015 (20,000 birds) and 2016 (25,000 birds). The beneficiaries (processors) processed both broilers and culled layers. However, more broilers were processed than culled layers. This suggests that broiler is the poultry meat type that is most preferred and consumed in the area probably due to its taste and appearance. This is in line with the findings of Salawu, Ibrahim, Lamidi and Sodeeq (2014) which revealed that the majority of the poultry consumers in Ibadan metropolis prefer broiler poultry meat. 
Creative Commons User License: CC BY-NC-ND

Abstracted by: EBSCOhost, Electronic Journals Service (EJS), Google Scholar, Journal Seek, Scientific Commons,

Food and Agricultural Organization (FAO), CABI and Scopus
Journal of Agricultural Extension

Vol. 23 (4) October, 2019

ISSN(e): 24086851; ISSN(Print); 1119944X

http://journal.aesonnigeria.org

http://www.ajol.info/index.php/jae

Email: editorinchief@aesonnigeria.org

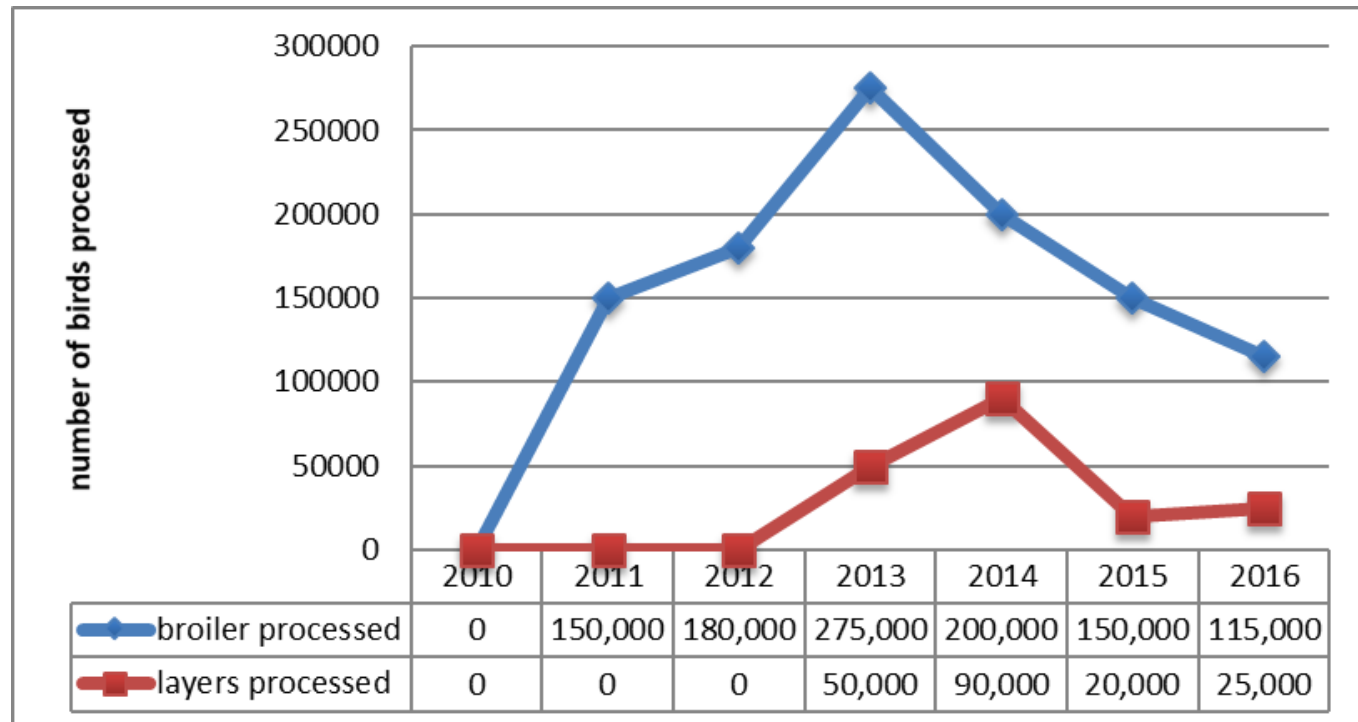

Figure 3: Commodities processed

Source: Field survey, 2017

\section{Marketing and Distribution Channels of Actors in Poultry Value Chain}

Figure 4 shows that the major marketing channels used by producers were individual consumers $(98.4 \%)$, wholesalers $(89.1 \%)$, hotels/restaurants $(68.8 \%)$ and eateries $(59.4 \%)$. Similarly, processors indicated that the major marketing channels were individual consumers $(100 \%)$, hotels/restaurants $(100 \%)$, eateries' $(100 \%)$, wholesalers $(50 \%)$ and retailers $(50 \%)$. The marketers used individual consumers $(100 \%)$, hotels/restaurants $(100 \%)$, retailers $(100 \%)$, eateries $(66.7 \%)$ and wholesalers $(66.7 \%)$ was the major marketing channels.

The results show that individual consumers, eateries, hotels/restaurants, and wholesalers are core marketing/distribution channels in poultry value chain. Assemblers were less used by the actors, perhaps due to fear of loss of bargaining power and good prices for poultry products, though their engagement could ensure steady market, particularly in seasons of glut. Usually farmers explore channels that promote good price for their product for profit maximization and sustainability of the business (Standing Committee for Economic and Commercial Cooperation of the Organization of the Islamic Cooperation (COMCEC) (2017). 
Creative Commons User License: CC BY-NC-ND

Abstracted by: EBSCOhost, Electronic Journals Service (EJS), Google Scholar, Journal Seek, Scientific Commons,

Food and Agricultural Organization (FAO), CABI and Scopus
Journal of Agricultural Extension

Vol. 23 (4) October, 2019

ISSN(e): 24086851; ISSN(Print); 1119944X

http://journal.aesonnigeria.org

http://www.ajol.info/index.php/jae

Email: editorinchief@aesonnigeria.org

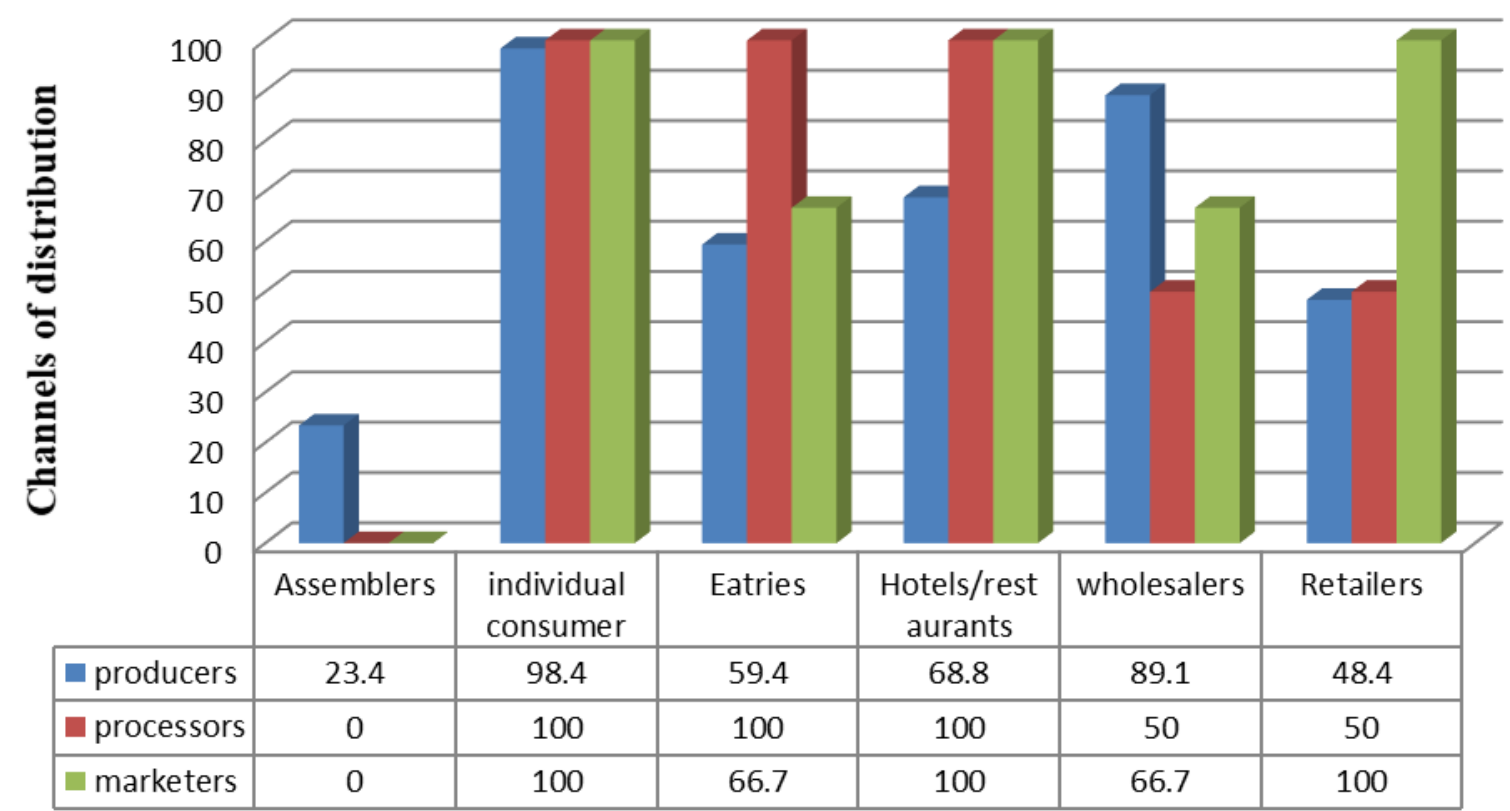

Figure 4: Marketing and distribution channels of actors

Source: Field survey, 2017

\section{Satisfaction of Poultry Value Chain Actors}

Service Providers Level of Satisfaction with Poultry Value Chain: Table 2 shows that the service providers were satisfied with linkage with other actors in the poultry value chain $(\bar{x}=2.50 ; \mathrm{Sd}=0.71)$, flow of fund for grant $(\bar{x}=2.50 ; \mathrm{Sd}=0.71)$, criteria for CIG formation ( $\bar{x}=2.50$; $\mathrm{Sd}=0.71$ ), commitment of project staff to actors $(\bar{x}=2.00 ; \mathrm{Sd}=0.00)$, use of group (CIGs) approach $(\bar{x}=2.00 ; \mathrm{Sd}=0.00)$, eligibility criteria for beneficiary participation ( $\bar{x}=2.00 ; \mathrm{Sd}=0.00)$ among others. However, the service providers expressed dissatisfaction with time of input supply, quality of extension services provided, size of grant approved etc. This suggests severe difficulty in poultry value chain development in the area since supply of farm inputs (such as day old chicks) and availability of fund is crucial for a sustainable poultry production (World Bank, 2013 and FAO, 2013). On the other hand, the service providers were satisfied with the linkage established by the value chain approach among the poultry value chain actors through the CIGs approach. This suggests that the actors will frequently share poultry value chain information which enhances their competitiveness (Aklilu et al, 2016).

Producers' Satisfaction with Poultry Value Chain: Table 2 shows that the producers were satisfied with linking with other actors in the poultry value chain $(\bar{x}=2.27 ; \mathrm{Sd}=0.80)$, commitment of project staff to actors $(\bar{x}=2.23 ; \mathrm{Sd}=0.83)$, frequency of contact with facilitators $(\bar{x}=2.14 ; \mathrm{Sd}=0.83)$, quality of technologies 
Creative Commons User License: CC BY-NC-ND

Abstracted by: EBSCOhost, Electronic Journals Service (EJS), Google Scholar, Journal Seek, Scientific Commons,

Food and Agricultural Organization (FAO), CABI and Scopus
Journal of Agricultural Extension

Vol. 23 (4) October, 2019

ISSN(e): 24086851; ISSN(Print); 1119944X

http://journal.aesonnigeria.org

http://www.ajol.info/index.php/jae

Email: editorinchief@aesonnigeria.org

delivered $(\bar{x}=2.14 ; \mathrm{Sd}=1.17)$, joint monitoring and coordination with the federal and state implementation agencies $(\bar{x}=2.09 ; \mathrm{Sd}=1.05)$, services provided by service providers $(\bar{x}=2.09$; $\mathrm{Sd}=0.87)$, facilitators involvement in decision making $(\bar{x}=2.05$; $\mathrm{Sd}=0.83)$, gender equality among beneficiaries $(\bar{x}=2.03 ; \mathrm{Sd}=0.67)$, time of input supply $(\bar{x}=2.00 ; \mathrm{Sd}=1.16)$ among others. Moreover, the producers were dissatisfied with quality of extension services provided, areas of trainings received, modalities for grant disbursement, size of grant approved etc. This suggests that the chances of innovation adoption by poultry producers in the value chain is slim since they have too few or no contact with extension services who play pertinent role in enabling application of new knowledge by livestock producers (Planning Commission, 2013).

Processors Satisfaction with Poultry Value Chain: Table 2 shows that the processors were satisfied with linkage with other actors in the poultry value chain $(\bar{x}=3.00 ; \mathrm{Sd}=1.41)$, frequency of contact with facilitators $(\bar{x}=3.00 ; \mathrm{Sd}=1.41)$, commitment of project staff to beneficiaries $(\bar{x}=3.00$; $\mathrm{Sd}=1.41)$, criteria for belonging to CADA ( $\bar{x}=3.00$; $\mathrm{Sd}=1.41)$, eligibility criteria for beneficiary participation $(\bar{x}=3.00$; $\mathrm{Sd}=1.41)$, value chains (maize, fruit-tress and poultry) selected in the state $(\bar{x}=3.00$; $\mathrm{Sd}=1.41)$, timely release of grant $(\bar{x}=3.00 ; \mathrm{Sd}=1.41)$ and time of input supply $(\bar{x}=2.50 ; \mathrm{Sd}=0.71)$. Other areas with favourable disposition from the processors were quality of trainings received $(\bar{x}=2.50 ; \mathrm{Sd}=2.12)$, quality of technologies delivered ( $\bar{x}=2.50 ; \mathrm{Sd}=2.12)$, conditions for participation in CADP $(\bar{x}=2.50 ; \mathrm{Sd}=0.71)$, services provided by service providers $(\bar{x}=2.50$; $\mathrm{Sd}=0.71)$ among others. Generally, the respondents (processors) were satisfied with the input, operational modalities, structure and implementation process of the programme. This suggests that the poultry processors segment of the value chain had the services of extension who offer quality trainings such as how to use sophisticated equipment being delivered to them (Hailemariam and Zemedu, 2018). However, the high standard deviation showed variation in the perception of processors. The positive perception of the processors suggests that the programme positively impacted on the beneficiaries. It is the result of good planning, participation of beneficiaries, monitory and evaluation mechanism anchored on evidence based policy.

Marketers' Satisfaction with Poultry Value Chain: Table 2 shows that the marketers were satisfied with areas of trainings received $(\bar{x}=2.67 ; \mathrm{SD}=1.16)$, linkage with other actors in the poultry value chain $(\bar{x}=2.67 ; \mathrm{SD}=1.16)$, time of input supply $(\bar{x}=2.33 ; \mathrm{SD}=0.58)$, gender equality among beneficiaries $(\bar{x}=2.33 ; \mathrm{SD}=0.58)$, commitment of project staff to beneficiaries $(\bar{x}=2.33 ; \mathrm{SD}=0.58)$, quality of trainings received ( $\bar{x}=2.33 ; \mathrm{SD}=0.58)$, frequency of contact with facilitators ( $\bar{x}=2.33$; $\mathrm{SD}=0.58)$, size of grant approved $(\bar{x}=2.33 ; \mathrm{SD}=1.53)$, services provided by facilitators ( $\bar{x}=2.33 ; \mathrm{SD}=0.58)$ and others. This suggests how well information flows among these actors as well as the efficiency of the market chain in enhancing the income of the poultry marketers (Kariuki, 2018). On the other hand, the marketers 
Creative Commons User License: CC BY-NC-ND

Abstracted by: EBSCOhost, Electronic Journals Service (EJS),

Google Scholar, Journal Seek, Scientific Commons,

Food and Agricultural Organization (FAO), CABI and Scopus
Journal of Agricultural Extension

Vol. 23 (4) October, 2019

ISSN(e): 24086851; ISSN(Print); 1119944X

http://journal.aesonnigeria.org

http://www.ajol.info/index.php/iae

Email: editorinchief@aesonnigeria.org

were not satisfied with involvement of facilitators in decision making and the size of grant

received. Similarly, the feature, structure, inputs of the programme and implementation

process equally appealed to the marketers. This suggests that the marketers received requisite training, services of facilitators and improved technologies disseminated, but their dissatisfaction with involvement of facilitators and volume of grant may have

hampered maximization of the benefits. This is because funds remain one of the major

production resources that drive the size of agricultural enterprise and often productivity.

Table 2: Satisfaction of the poultry value chain by actors

\begin{tabular}{|c|c|c|c|c|c|c|c|c|}
\hline \multirow[t]{2}{*}{ Perception variables } & \multicolumn{2}{|c|}{$\begin{array}{l}\text { Service provider } \\
\text { Mean }\end{array}$} & \multicolumn{2}{|c|}{$\begin{array}{l}\text { Farmers } \\
\text { Mean }\end{array}$} & \multicolumn{2}{|c|}{$\begin{array}{l}\text { Processors } \\
\text { Mean }\end{array}$} & \multicolumn{2}{|c|}{$\begin{array}{c}\text { Marketers } \\
\text { Mean }\end{array}$} \\
\hline & $(\overline{\mathrm{x}})$ & sd & $(\bar{x})$ & sd & $(\bar{x}$ & sd & & sd \\
\hline Time of input supply & 1.50 & 0.71 & 2.00 & 1.16 & 2.50 & 0.71 & 2.33 & 0.58 \\
\hline $\begin{array}{l}\text { Quality of extension services } \\
\text { provided }\end{array}$ & 0.00 & 0.00 & 1.47 & 1.32 & 2.00 & 2.83 & 1.00 & 1.73 \\
\hline $\begin{array}{l}\text { Linkage with other actors in the } \\
\text { poultry value chain }\end{array}$ & 2.50 & 0.71 & 2.27 & 0.80 & 3.00 & 1.41 & 2.67 & 1.16 \\
\hline Frequency of contact with facilitators & 1.00 & 1.41 & 2.14 & 0.83 & 3.00 & 1.41 & 2.33 & 0.58 \\
\hline Frequency of trainings received & 0.50 & 0.71 & 1.69 & 0.69 & 2.00 & 1.41 & 2.00 & 1.00 \\
\hline Gender equality among beneficiaries & 1.50 & 0.71 & 2.03 & 0.67 & 2.00 & 0.00 & 2.33 & 0.58 \\
\hline $\begin{array}{l}\text { Commitment of project staff to } \\
\text { beneficiaries }\end{array}$ & 2.00 & 0.00 & 2.23 & 0.83 & 3.00 & 1.41 & 2.33 & 0.58 \\
\hline Quality of trainings received & 1.50 & 0.71 & 1.92 & 0.86 & 2.50 & 2.12 & 2.33 & 0.58 \\
\hline Quality of technologies delivered & 1.00 & 0.00 & 2.14 & 1.17 & 2.50 & 2.12 & 2.00 & 1.00 \\
\hline timely release of grant & 1.50 & 0.71 & 1.70 & 0.83 & 3.00 & 1.41 & 2.33 & 0.58 \\
\hline Conditions for participation in CADP & 1.50 & 0.71 & 1.73 & 1.04 & 2.50 & 0.71 & 2.00 & 1.00 \\
\hline Size of grant approved & 0.00 & 0.00 & 1.59 & 0.97 & 1.50 & 2.12 & 1.67 & 1.53 \\
\hline Services provided by facilitators & 0.50 & 0.71 & 1.91 & 0.94 & 2.00 & 1.41 & 2.00 & 1.00 \\
\hline $\begin{array}{l}\text { Services provided by service } \\
\text { providers }\end{array}$ & 1.50 & 0.71 & 2.09 & 0.87 & 3.00 & 1.41 & 2.33 & 1.53 \\
\hline Areas of trainings received & 1.50 & 0.71 & 1.70 & 1.05 & 2.00 & 1.41 & 2.33 & 0.58 \\
\hline Criteria for grant procurement & 1.50 & 0.71 & 1.59 & 1.18 & 2.50 & 0.71 & 2.33 & 0.58 \\
\hline Use of group (CIGs) approach & 2.00 & 0.00 & 1.97 & 1.05 & 2.00 & 0.00 & 2.67 & 1.16 \\
\hline Modalities for disbursement & 1.50 & 0.71 & 1.42 & 0.99 & 2.50 & 0.71 & 2.33 & 0.58 \\
\hline Criteria for belonging to CADA & 1.50 & 0.71 & 1.62 & 1.05 & 3.00 & 1.41 & 2.33 & 0.58 \\
\hline Flow of fund for grant & 2.50 & 0.71 & 1.73 & 1.09 & 2.50 & 0.71 & 2.00 & 1.00 \\
\hline Criteria for $\mathrm{CIG}$ formation & 2.50 & 0.71 & 1.83 & 1.03 & 2.00 & 1.41 & 2.33 & 0.58 \\
\hline $\begin{array}{l}\text { Eligibility criteria for beneficiary } \\
\text { participation }\end{array}$ & 2.00 & 0.00 & 1.72 & 1.12 & 3.00 & 1.41 & 2.00 & 1.00 \\
\hline $\begin{array}{l}\text { Value chains (maize, fruit-tress and } \\
\text { poultry) selected in the state }\end{array}$ & 2.00 & 0.00 & 1.98 & 1.28 & 3.00 & 1.41 & 2.33 & 1.53 \\
\hline $\begin{array}{l}\text { Organizing CIGs n CADA by } \\
\text { facilitators }\end{array}$ & 2.00 & 0.00 & 1.92 & 0.93 & 2.50 & 0.71 & 2.00 & 1.00 \\
\hline $\begin{array}{l}\text { Facilitators guiding group members in } \\
\text { decision making } \\
\text { Joint monitoring and coordination }\end{array}$ & 1.00 & 1.41 & 2.05 & 0.83 & 2.00 & 0.00 & 1.67 & 1.53 \\
\hline $\begin{array}{l}\text { with the federal and state } \\
\text { implementation agencies }\end{array}$ & 0.50 & 0.71 & 2.09 & 1.05 & 2.00 & 0.00 & 1.67 & 1.53 \\
\hline
\end{tabular}


Creative Commons User License: CC BY-NC-ND

Abstracted by: EBSCOhost, Electronic Journals Service (EJS), Google Scholar, Journal Seek, Scientific Commons,

Food and Agricultural Organization (FAO), CABI and Scopus
Journal of Agricultural Extension

Vol. 23 (4) October, 2019

ISSN(e): 24086851; ISSN(Print); 1119944X

http://journal.aesonnigeria.org

http://www.ajol.info/index.php/iae

Email: editorinchief@aesonnigeria.org

\section{Challenges Faced by Actors in Poultry Value Chain of CADP}

Challenges of service providers in poultry value chain: Table 3 shows the perceived challenges of service providers in the poultry value chain of CADP. From the Table, the challenges include: inadequate funding $(\bar{x}=4.00 ; \mathrm{Sd}=0.00)$, low extension contact ( $\bar{x}=3.50 ; \mathrm{Sd}=0.71)$, poor linkage with research $(\bar{x}=3.50 ; \mathrm{Sd}=0.71)$, inadequate/lack of understanding of VC paradigm ( $\bar{x}=3.00 ; \mathrm{Sd}=0.00)$, literacy problem of poultry farmers $(\bar{x}=3.0 ; \mathrm{Sd}=0.00)$, insufficient/lack of stable power supply $(\mathrm{M}=3.00$; $\mathrm{Sd}=0.00)$, high cost of recharge card $(\bar{x}=3.50 ; \mathrm{Sd}=0.71)$, poor linkage with other actors ( $\bar{x}=2.50 ; \mathrm{SD}=2.12)$, its time consuming $(\bar{x}=2.50 ; \mathrm{Sd}=0.71)$, gender barriers on ownership and use of mobile phones ( $\bar{x}=2.50 ; \mathrm{Sd}=0.71)$ among others. This finding is consistent with that of Nwobodo (2017) that lack of extension contacts and poor linkage with research are among the major challenges faced by input dealers in Makurdi, Benue State. The implication is that poultry value chain actors in the area will not have quality and adequate information on input use which hitherto, will undermine the quality of technologies and information they deliver to the actors.

Challenges of producers in poultry value chain: Table 3 shows the perceived challenges of producers in the poultry value chain of CADP. From the Table, the challenges include: high cost of agro-inputs ( $\bar{x}=3.27$; $\mathrm{Sd}=0.93)$, unavailability/poor access to labor ( $\bar{x}=3.05$; $\mathrm{Sd}=0.70)$, high cost of labor ( $\bar{x}=3.03$; $\mathrm{Sd}=0.91)$, poor linkage with research $(\bar{x}=3.02 ; \mathrm{Sd}=1.28)$, low extension contact $(\bar{x}=3.00 ; \mathrm{Sd}=1.29)$, poor transportation network ( $\bar{x}=3.00 ; \mathrm{Sd}=1.07)$, insufficient/lack of stable power supply $(\bar{x}=2.97$; Sd=1.15), insufficient market $(\bar{x}=2.97$; $\mathrm{Sd}=0.99)$, competition from fellow actors $(\bar{x}=2.89 ; \mathrm{Sd}=1.18)$, inadequate access to inputs e.g. chicken $(\bar{x}=2.81$; $\mathrm{Sd}=1.08)$, lack of basic infrastructure $(\bar{x}=2.80 ; \mathrm{Sd}=1.04)$, inadequate training/advisory services by service providers ( $\bar{x}=2.75$; $\mathrm{Sd}=1.07)$, insufficient/lack of trust amongst actors ( $\bar{x}=2.72$; $S d=1.15)$ among others.

This finding corroborates that of Nwobodo (2017) who found that poor attitude of farmers in communicating useful information to other actors, lack of stable power supply, poor mobile phone coverage and high cost of recharge cards are among the major challenges of rice farmers in Makurdi, Benue State. Thwala (2011), states that lack of management skills for local chickens, high mortality due to poor animal health care in remote areas, poorly organized market channels, poorly organized technology transfer, low availability of technical personnel, poor farmers' commodity groups and high input cost are the major challenges of poultry producers in SubSaharan Africa. The implication of this finding is that the involvement of the poultry producers in the poultry value chain will be deterred by these challenges which will drastically reduce their return on investment and participation in the global value chain.

Challenges of processors in poultry value chain: Table 3 shows the perceived challenges of processors in the poultry value chain of CADP. From the Table, the challenges include: poor condition of basic infrastructure e.g. roads $(\bar{x}=4.00$; $\mathrm{Sd}=0.00)$, high cost of mobile phone $(\bar{x}=3.50 ; \mathrm{Sd}=0.71)$, insufficient/lack of stable 
Creative Commons User License: CC BY-NC-ND

Abstracted by: EBSCOhost, Electronic Journals Service (EJS), Google Scholar, Journal Seek, Scientific Commons,

Food and Agricultural Organization (FAO), CABI and Scopus
Journal of Agricultural Extension

Vol. 23 (4) October, 2019

ISSN(e): 24086851; ISSN(Print); 1119944X

http://journal.aesonnigeria.org

http://www.ajol.info/index.php/iae

Email: editorinchief@aesonnigeria.org

power supply $(\bar{x}=3.50 ; \mathrm{Sd}=0.71)$, problem of proximity $(\bar{x}=3.50 ; \mathrm{Sd}=0.71)$, poor transportation network ( $\bar{x}=3.50 ; \mathrm{Sd}=0.71)$, inadequate/lack of understanding of VC paradigm ( $\bar{x}=3.00 ; \mathrm{Sd}=1.41)$, literacy problem of poultry farmers $(\bar{x}=3.00 ; \mathrm{Sd}=0.00)$, low extension contact $(\bar{x}=3.00 ; \mathrm{Sd}=1.41)$, poor linkage with research $(\bar{x}=3.00$; $\mathrm{Sd}=1.41)$, high cost of agro-inputs $(\bar{x}=3.00 ; \mathrm{Sd}=0.00)$, unavailability/poor access to labour ( $\bar{x}=2.50 ; \mathrm{Sd}=2.12)$, gender disparity on access to inputs $(\bar{x}=2.50 ; \mathrm{Sd}=2.12)$, inadequate training/advisory services by service providers $(\bar{x}=2.50 ; \mathrm{Sd}=0.71)$, insufficient market ( $\bar{x}=2.50$; $\mathrm{Sd}=2.121)$ among others. The problem of high cost of mobile (facilities) and lack of basic infrastructure are consistent with Mng'ong'ose and Victor (2018) who found that high cost of facilities, unavailability of infrastructure, lack of skills and language barriers were among the challenges to use of ICTs tools in rural areas of Tanzania. When the processors are lacking in ICT tools and skills, they tend to disregard the use even when it is beneficial to their linkage with other actors in the value chain. This suggests that the processors would often encounter difficulty and delay in accessing live birds from producers because of the bridge in ease of communication. 
Creative Commons User License: CC BY-NC-ND

Journal of Agricultural Extension

Abstracted by: EBSCOhost, Electronic Journals Service (EJS), Vol. 23 (4) October, 2019

Google Scholar, Journal Seek, Scientific Commons,

ISSN(e): 24086851; ISSN(Print); 1119944X

Food and Agricultural Organization (FAO), CABI and Scopus

http://journal.aesonnigeria.org

http://www.ajol.info/index.php/iae

http://eoi.citefactor.org/10.11226/v23i4

Email: editorinchief@aesonnigeria.org

Table 3: Challenges faced by actors in poultry value chain

\begin{tabular}{|c|c|c|c|c|c|c|c|c|}
\hline Challenges encountered & $\begin{array}{l}\text { Service } \\
\text { provider } \\
\text { Mean } \\
(\bar{x})\end{array}$ & \multicolumn{3}{|c|}{ Farmers } & $\begin{array}{l}\text { Proces } \\
\text { sors } \\
\text { Mean } \\
\text { (x) }\end{array}$ & \multicolumn{2}{|r|}{$\begin{array}{c}\text { Mar } \\
\text { kete } \\
\text { rs } \\
\text { Mea } \\
\text { n } \\
(\bar{x})\end{array}$} & Sd \\
\hline Competition from fellow actors & 2.00 & 1.414 & 2.89 & 1.183 & 1.50 & 0.707 & 2.67 & 1.528 \\
\hline Poor linkage with other actors & 2.50 & 2.121 & 2.48 & 0.891 & 1.00 & 0.000 & 2.33 & 1.155 \\
\hline Insufficient/Lack of trust amongst actors & 2.00 & 1.414 & 2.72 & 1.147 & 2.00 & 1.414 & 1.67 & 1.155 \\
\hline Disperse location of farmers/marketers & 1.00 & 0.000 & 2.52 & 1.141 & 1.50 & 0.707 & 2.67 & 1.528 \\
\hline $\begin{array}{l}\text { Insufficient/lack of information on consumer } \\
\text { preference }\end{array}$ & 2.00 & 1.414 & 2.08 & 0.981 & 1.50 & 0.707 & 2.33 & 1.155 \\
\hline Inadequate/lack of understanding of VC paradigm & 3.00 & 0.000 & 2.56 & 1.153 & 3.00 & 1.414 & 1.67 & 1.155 \\
\hline Its time consuming & 2.50 & 0.707 & 1.91 & 1.137 & 2.00 & 1.414 & 2.67 & 0.577 \\
\hline Unavailability of mobile phone network & 2.00 & 1.414 & 2.22 & 1.228 & 0.00 & 0.000 & 2.33 & 1.155 \\
\hline lack of basic infrastructure e.g. roads & 2.00 & 1.414 & 2.80 & 1.042 & 4.00 & 0.000 & 2.67 & 1.528 \\
\hline Gender disparity on access to inputs & 1.00 & 0.000 & 1.92 & 1.103 & 2.50 & 2.121 & 2.00 & 1.000 \\
\hline Poor mobile phone network coverage & 1.00 & 0.000 & 2.25 & 1.247 & 1.00 & 0.000 & 1.00 & 0.000 \\
\hline Literacy problem of poultry farmers & 3.00 & 0.000 & 2.58 & 1.110 & 3.00 & 0.000 & 2.33 & 1.155 \\
\hline Inadequate access to inputs e.g. chicken & 2.00 & 1.414 & 2.81 & 1.082 & 1.00 & 0.000 & 2.33 & 1.155 \\
\hline Inadequate/Lack of market information & 1.00 & 0.000 & 2.39 & 1.107 & 1.00 & 0.000 & 2.33 & 1.155 \\
\hline $\begin{array}{l}\text { poor attitude of actors in communicating useful } \\
\text { information to other actors }\end{array}$ & 1.00 & 0.000 & 2.59 & 1.035 & 1.00 & 0.000 & 2.33 & 1.155 \\
\hline Differences in language of other actors & 2.00 & 1.414 & 1.23 & 1.282 & 0.00 & 0.000 & 0.33 & 0.577 \\
\hline Differences in culture of other actors & 2.00 & 1.414 & 1.14 & 1.193 & 0.00 & 0.000 & 0.33 & 0.577 \\
\hline lack of mobile phone & 0.00 & 0.000 & 0.75 & 1.008 & 0.00 & 0.000 & 0.00 & 0.000 \\
\hline Inability to operate mobile phone & 0.50 & 0.707 & 1.19 & 1.296 & 0.00 & 0.000 & 0.00 & 0.000 \\
\hline Inability to read and understand text messages & 0.50 & 0.707 & 1.23 & 1.377 & 0.50 & 0.707 & 0.00 & 0.000 \\
\hline $\begin{array}{l}\text { Poor interest in using mobile phones to link up } \\
\text { with other actors }\end{array}$ & 1.00 & 0.000 & 1.33 & 1.392 & 0.00 & 0.000 & 0.33 & 0.577 \\
\hline High cost of mobile phone & 0.50 & 0.707 & 1.86 & 1.367 & 3.50 & 0.707 & 0.33 & 0.577 \\
\hline Inadequate/Lack of stable power supply & 3.00 & 0.000 & 2.97 & 1.154 & 3.50 & 0.707 & 2.00 & 1.732 \\
\hline $\begin{array}{l}\text { Gender barriers on ownership and use of mobile } \\
\text { phones }\end{array}$ & 2.50 & 0.707 & 1.92 & 1.172 & 0.50 & 0.707 & 2.00 & 1.732 \\
\hline Low extension contact & 3.50 & 0.707 & 3.00 & 1.297 & 3.00 & 1.414 & 2.67 & 2.31 \\
\hline Poor linkage with research & 3.50 & 0.707 & 3.02 & 1.279 & 3.00 & 1.414 & 2.33 & 2.082 \\
\hline High cost of recharge card & 3.50 & 0.707 & 2.03 & 1.284 & 0.50 & 0.707 & 2.33 & 1.155 \\
\hline Inadequate funding & 4.00 & 0.000 & - & - & - & - & 4.00 & 0.000 \\
\hline Problem of proximity & - & - & 2.17 & 1.176 & 3.50 & 0.707 & - & - \\
\hline High cost of agro-inputs & - & - & 3.27 & 0.930 & 3.00 & 0.000 & - & - \\
\hline Unavailability/poor access to labour & - & - & 3.05 & 0.700 & 2.50 & 2.121 & - & - \\
\hline High cost of labour & - & - & 3.03 & 0.908 & 2.00 & 2.828 & - & - \\
\hline Exploitation of poultry processors by input dealers & - & - & 2.39 & 1.121 & 1.00 & 0.000 & - & - \\
\hline Supply of light weight chicken & - & - & 2.19 & 1.233 & 0.50 & 0.707 & - & - \\
\hline $\begin{array}{l}\text { Inadequate training/advisory services by service } \\
\text { providers }\end{array}$ & - & - & 2.75 & 1.069 & 2.50 & 0.707 & - & - \\
\hline Poor transportation network & - & - & 3.00 & 1.069 & 3.50 & 0.707 & - & - \\
\hline Insufficient market & - & - & 2.97 & 0.992 & 2.50 & 2.121 & - & - \\
\hline
\end{tabular}

Field survey, 2017 
Creative Commons User License: CC BY-NC-ND

Abstracted by: EBSCOhost, Electronic Journals Service (EJS),

Google Scholar, Journal Seek, Scientific Commons,

Food and Agricultural Organization (FAO), CABI and Scopus

http://eoi.citefactor.org/10.11226/v23i4
Journal of Agricultural Extension

Vol. 23 (4) October, 2019

ISSN(e): 24086851; ISSN(Print); 1119944X

http://journal.aesonnigeria.org

http://www.ajol.info/index.php/jae

Email: editorinchief@aesonnigeria.org

Challenges of marketers in poultry value chain: Table 3 shows the perceived challenges of marketers in the poultry value chain of CADP. From the Table, the challenges include: inadequate funding $(\bar{x}=4.00 ; \mathrm{Sd}=0.00)$, competition from fellow actors ( $\bar{x}=2.67 ; \mathrm{Sd}=1.53)$, disperse location of farmers/marketers $(\bar{x}=2.67 ; \mathrm{Sd}=1.53)$, its time consuming ( $\bar{x}=2.67$; $\mathrm{Sd}=1.58)$, lack of basic infrastructure e.g. roads $(\bar{x}=2.67$; $\mathrm{Sd}=1.53)$, low extension contact $(\bar{x}=2.67 ; \mathrm{Sd}=2.31)$, poor linkage with other actors $(\bar{x}=2.33$; $\mathrm{Sd}=1.16)$, inadequate/lack of information on consumer preference $(\bar{x}=2.33$; $\mathrm{Sd}=1.16)$, unavailability of mobile phone network $(\bar{x}=2.33$; $\mathrm{Sd}=1.16)$, literacy problem of poultry farmers $(\bar{x}=2.33$; $\mathrm{Sd}=1.16)$, inadequate access to inputs e.g. chicken $(\bar{x}=2.33$; $\mathrm{Sd}=1.16$ ) among others. This finding shows that the participation of the poultry marketers in the value chain will be constrained by these challenges. Limited access to funds by the poultry marketers suggests that they will rarely have adequate poultry products available at their disposal to satisfy their customers demand.

\section{Conclusion and Recommendation}

The poultry value chain actors perceived the value chain approach of CADP to be satisfactory in the following areas: linkage with other actors in poultry value chain, commitment of project staff to the beneficiaries. Challenges faced by the poultry value chain actors include: its time consuming, literacy problem, low extension contact and poor linkage with research. Hence, extension efforts need to be directed towards developing the skills and strengthening the capabilities of small-scale farmers to become more competitive and profitable. Extension agencies need to revisit the production-oriented farming systems and assist farmers in adopting a more marketoriented approach. Government should organize trainings for capacity building of farmers on the gains of adopting the value chain approach through extensions agents by providing the extension agents with the required logistics.

\section{References}

Achimugu, H., Abubakar, Y. I., Agboni, J. U. and Orokpo, J. O. (2012). Rethinking poverty reduction and sustainable development in Nigeria: An advocacy for the buttom-top paradigm. Canadian Social Science Vol. 8, No. 6, 2012, pp. 78-90 DOI:10.3968/j.css.1923669720120806.2741

Ahungwa, G. T., Haruna, U. and Rakiya, Y. A. (2014). Trend analysis of the contribution of agriculture to the Gross Domestic Product of Nigeria (1960 - 2012). Journal of Agriculture and Veterinary Science (IOSR-JAVS) Volume 7, Issue 1, Ver. IV (Feb. 2014), PP 50-55. Retrieved from www.iosriournals.org 
Creative Commons User License: CC BY-NC-ND

Abstracted by: EBSCOhost, Electronic Journals Service (EJS),

Google Scholar, Journal Seek, Scientific Commons,

Food and Agricultural Organization (FAO), CABI and Scopus

http://eoi.citefactor.org/10.11226/v23i4
Journal of Agricultural Extension

Vol. 23 (4) October, 2019

ISSN(e): 24086851; ISSN(Print); 1119944X

http://journal.aesonnigeria.org

http://www.ajol.info/index.php/jae

Email: editorinchief@aesonnigeria.org

Aklilu Hailemichael, Berhanu Gebremedhin, Solomon Gizaw and Azage Tegegne (2016). Analysis of village poultry value chain in Ethiopia: Implications for action research and development

Antai, A. S., Udo, A. B. and Effiong, C. E. (2016). Analysis of the sectoral linkages and growth prospects in the Nigerian economy. Journal of Economics and Finance (IOSR JEF) Volume 7, Issue 6 Ver. I (Nov. - Dec. 2016), PP 73-80. www.iosrjournals.org

Anyadiegwu, A. O. (2013). Environmental and Social Management Plan (ESMP) for fruit juice production and packaging for promise kept farmers multi-purpose cooperative society. 2 Masaka Close, Off Olusegun Obasanjo Way, Wuse, Zone 7, Abuja.

Central Bank of Nigeria (CBN) (2010). Central Bank of Nigeria: Statistical Bulletin, 2010 Edition

Chikaire, J. U., Ani, A. O., Atoma, C. N. and Tijjani, A. R. (2015) Capacity Building: Key to Agricultural Extension Survival. Scholars Journal of Agriculture and Veterinary Sciences Vol. 2(1A):13-21

Ekpo, A. H. and Umoh, O. J. (2012). An overview of the Nigerian economic growth and development. Daily Newspaper on Saturday July 14, 2012.

Food and Agricultural Organization (FAO), 2013. Guidelines for input trade fairs and voucher schemes. Food and Agriculture Organization of the United Nations (FAO), Rome, Italy. http://www.fao.org/docrep/018/aq418e/aq418e.pdf.

Food and Agricultural Organization (FAO) (2013). FAO Statistics: Food and Agricultural Organisation of the United Nations. http://faostat.fao.org/site/573/default.aspx\#ancor.

Haggblade, S., Theriault, V., Staatz, J., Dembele, N. and Diallo, B. (2012) A conceptual framework for promoting inclusive agricultural value chains. Michigan State University Department of Agricultural, Food and Resource Economics

Heise, H., Crisan, A. and Theuvsen, L. (2015) The poultry market in Nigeria: Market structures and potential for investment in the market. International Food and Agribusiness Management Review Volume 18 Special Issue A, 2015

Kariuki, P. (2018) Poultry marketing. Kenya poultry farmers association FAO-ILRI regional training workshop on provon livestock technologies ILRI, Addis Ababa, 3-5 December 2018

Klerkx, L., Schut, M., Leeuwis, C. and Kilelu, C. (2012). Advances in knowledge brokering in the agricultural sector: Towards innovation system facilitation. IDS Bulletin 43(5):53-60.

Mng'ong'ose, W. A. and Victor, M. (2018). Challenges facing adoption of ICT in rural areas of Tanzania. International Journal of Economics, Business and Management Research Vol. 2 (1) 343-354

National Bureau of Statistics (NBS) (2010). NBS/CADP Baseline survey report Abuja, Nigeria 
Creative Commons User License: CC BY-NC-ND

Abstracted by: EBSCOhost, Electronic Journals Service (EJS),

Google Scholar, Journal Seek, Scientific Commons,

Food and Agricultural Organization (FAO), CABI and Scopus

http://eoi.citefactor.org/10.11226/v23i4
Journal of Agricultural Extension

Vol. 23 (4) October, 2019

ISSN(e): 24086851; ISSN(Print); 1119944X

http://journal.aesonnigeria.org

http://www.ajol.info/index.php/jae

Email: editorinchief@aesonnigeria.org

National Bureau of Statistics (NBS) (2017). Nigerian Gross Domestic Product Report - Q3 2017.

Noko, E.J (2016). Economic recession in Nigeria: Causes and solution, Published by educLn.com2016 http://educacinfo.com/economic- recession- nigeria/

Nwobodo, C. E. (2017). Communication linkages among actors in the rice value chain in Nasarawa and Benue States, Nigeria. A Ph.D. thesis. Department of Agricultural Extension, University of Nigeria

Nwobodo, C. E. and Ajah, O. E. (2016). Assessment of linkages between agro-input dealers and other stakeholders in rice value chain in Ebonyi State, Nigeria. A paper presented at the Rice Africa $5^{\text {th }}$ Annual International Conference, Abuja, Nigeria, 18-21 ${ }^{\text {st }}$ May.

Obiora, C. J. and Emodi, A. I. (2013). Restructuring the agricultural extension service for effective agricultural transformation agenda in Nigeria Greener Journal of Agricultural Science, 3(6):511-517.

Ogunlade, I., Atibioke, O. A., Ladele, A. A. and Adumadehin, G. S. (2012). Capacity of agro input dealers in advisory service delivery to maize farmers in Kwara State, Nigeria. International Research Journal of Agricultural Science and Soil Science (ISSN: 2251 0044) Vol. 2(10) pp. 426-435.

Opara U. N. (2010). Personal and socio economic determinants of agricultural information use by farmers in the Agricultural development Programme (ADP) Zones of Imo State, Nigeria. Library Philospphy and practice, Available online at: http://unilib.unl.edu/LPP/opara.htm.

Planning Commission (2013). XIII Five Year Plan Plan Report on Economic Analysis, Volume II.

Salawu, M. B., Ibrahim, A. G., Lamidi, L. O. and Sodeeq, A. E. (2014). Consumption and consumer preference for poultry meat types in Ibadan Metropolis. Journal of Economics and Sustainable Development Vol. 5, No.28, 20-25

Standing Committee for Economic and Commercial Cooperation of the Organization of the Islamic Cooperation (COMCEC) (2017). Improving agricultural market performance: Creation and development of market institutions. Prepared by Investment Consulting Associates for the COMCEC coordination Office, Ankara: COMCEC.

Thwala, M. S. (2011). Analysing the value chain of the family poultry sub sector in the lower usuthu project area in Swaziland. Report prepared during the assignment as Associate Poultry Adviser for the IFAD funded FAO project "Smallholder Poultry Development" (GCP/INT/197/IFA)

Ugwu, D. S. (2009). Baseline study of small and medium scale poultry production in Enugu and Lagos States of Nigeria. World Journal of Agricultural Sciences 5 (1): pp 27-33, 2009 ISSN 1817-3047 
Creative Commons User License: CC BY-NC-ND

Abstracted by: EBSCOhost, Electronic Journals Service (EJS),

Google Scholar, Journal Seek, Scientific Commons,

Food and Agricultural Organization (FAO), CABI and Scopus

http://eoi.citefactor.org/10.11226/v23i4
Journal of Agricultural Extension

Vol. 23 (4) October, 2019

ISSN(e): 24086851; ISSN(Print); 1119944X

http://journal.aesonnigeria.org

http://www.ajol.info/index.php/jae

Email: editorinchief@aesonnigeria.org

World Bank, 2013. Unlocking Africa's Agricultural Potential. Washington, DC, USA. https://openknowledge.worldbank.org/handle/10986/16624. 